\title{
Cell Wall Enzymes and Cell Wall Changes in 'Flavortop' Nectarines: mRNA Abundance, Enzyme Activity, and Changes in Pectic and Neutral Polymers during Ripening and in Woolly Fruit
}

\author{
Hong-Wei Zhou, Lilian Sonego, Andrai Khalchitski, Ruth Ben-Arie, Amnon Lers, and Susan Lurie ${ }^{1}$ \\ Department of Postharvest Science, Agricultural Research Organization, The Volcani Center, PO Box 6, Bet \\ Dagan 50 250, Israel
}

AdDitional INDEX WORDs. chilling injury, polygalacturonase, pectin esterase, Prunus persica, $\beta$-1,4-glucanase

\begin{abstract}
Most 'Flavortop' nectarines [Prunus persica (L.) Batsch (Nectarine Group)] that were placed directly into $0{ }^{\circ} \mathrm{C}$ storage developed chilling injury after removal, while preconditioning fruit for 2 days at $20{ }^{\circ} \mathrm{C}$ (delayed storage) reduced chilling injury substantially. Chilling injury was expressed as the development of a dry, woolly flesh texture during ripening. Delayed-storage fruit were as firm as control fruit when placed in storage, but softened more during storage. Analysis of cell wall components showed that in woolly fruit a higher percentage of pectin was retained in the sodium carbonate fraction, although during ripening polymers in this fraction decreased in molecular mass (Mr). In the guanidine thiocyanate hemicellulose fraction of woolly fruit, the associated pectin and hemicellulose remained as large polymers, while in delayedstorage fruit they decreased in Mr during ripening. Endo-polygalacturonase (PG), pectin esterase (PE), and endo-glucanase (EGase) activities of delayed-storage fruit were the same as control fruit at the beginning of storage, although exo-PG was higher. However, differences were observed at the end of storage. Endo-PG activity was lower in control than delayed-storage fruit at the end of storage while PE activity was higher, and exo-PG and EGase activities were similar. These differences in activity were not reflected in the mRNA abundance of the respective enzymes. Endo-PG and PE message was similar in all fruit at the end of storage and increased during ripening, while EGase message was low at all times except in control fruit after storage and development of woolliness. Prevention of chilling injury by delayed storage appears to be due to the ability of the fruit to continue a progressive, slow cell wall degradation in storage which allows normal ripening to proceed when the fruit are rewarmed. Regulation of the softening process did not appear to be by enzyme synthesis, since mRNA levels of the enzymes did not correspond with enzyme activity.
\end{abstract}

Woolliness is a physiological disorder of nectarines [Prunus persica (Nectarine Group)] and peaches [Prunus persica (Peach Group)] whereby they fail to ripen normally after prolonged periods of $0^{\circ} \mathrm{C}$ storage, resulting in a lack of juice and a dry, woolly texture. This undesirable texture of the flesh due to chilling injury has been associated with unbalanced cell wall metabolism in the fruit. Woolliness has been attributed to impaired solubilization of pectic substances with accumulation of insoluble low methoxyl pectin of high molecular mass (Mr) (Ben-Arie and Lavee, 1971). Attempts to understand woolliness have focused on activities of polygalacturonase (PG) and pectin esterase (PE). During normal ripening, PG activity increases and $\mathrm{PE}$ activity decreases along with an increase in water soluble pectin (Ben-Arie and Lavee, 1971; Ben-Arie and Sonego, 1980; Buescher and Furmanski, 1978; Pressey and Avants, 1973). Ben-Arie and Sonego (1980) found an increase in PE activity and inhibition of $\mathrm{PG}$ activity in $0{ }^{\circ} \mathrm{C}$ stored fruit. This imbalance in activity was proposed to lead to inadequate digestion of the pectin polymers and accumulation of high Mr pectin with low levels of esterification. It has not been determined whether different levels of enzyme activities following cold storage are due to altered synthesis or activity.

Changes in endo- $\beta$-1,4-D-glucanase (EGase or cellulase) are associated with modifications in cell wall structure that accompany

\footnotetext{
Received for publication 26 Aug. 1999. Accepted for publication 28 Apr. 2000. This research was funded partially by the Binational Agricultural Research and Development (BARD) Fund between the United States and Israel No. 4052. The cost of publishing this paper was defrayed in part by the payment of page charges. Under postal regulations, this paper therefore must be hereby marked advertisement solely to indicate this fact.

'Corresponding author; e-mail; zeslov@netvision.net.il.
}

many developmental processes, including ripening (Fisher and Bennett, 1991). The role of this enzyme in contributing to cell wall changes which encourage woolliness has not been investigated, although recently one isoform was found to increase in activity during normal peach ripening (Bonghi et al., 1998).

Another approach to the problem of woolliness is to examine cell wall polymer changes during normal and abnormal ripening. Unfractionated cell wall extracts do not allow discrimination between pectic and hemicellulosic polymers. With fractionation it is possible to observe that normal nectarine ripening results in solubilization of pectin polymers of high $\mathrm{Mr}$ and depolymerization at a later stage (Dawson et al., 1992; Lurie et al., 1994). Woolliness may result from incomplete degradation of cell wall pectins, including the neutral sugar side chains (Dawson et al., 1992; Lill et al., 1989; Lurie et al., 1994). Polymers representing the hemicellulose fraction of cell walls have rarely been examined for their contribution to normal or abnormal ripening in peaches or nectarines (Dawson et al., 1992).

Most studies comparing healthy and woolly fruit have compared fruit ripened without storage with fruit following prolonged cold storage (Dawson et al., 1992; Hobbs et al, 1991). It would be useful to have a comparison of stored fruit which do not develop woolliness with those that do. Such a comparison is possible by holding nectarines for $2 \mathrm{~d}$ at room temperature before cold storage (delayed storage). This regime will delay or prevent the appearance of woolliness in the stored fruit (Zhou et al., 1999) and allow concomitant examination of stored fruit which will ripen normally and abnormally.

This research tested the hypothesis that development of woolliness in nectarines is due to an imbalance in the activities of PG and 
PE following cold storage which leads to accumulation in fruit cell walls of insoluble pectin with low esterification which will bind extracellular juice. Activities of PG and PE and mRNA abundance of these enzymes were examined during ripening after harvest and after cold storage, with and without delayed storage to prevent woolliness. The sequence of changes in pectic polysaccharides during normal ripening and in fruit after storage were also studied. In addition, the activity and mRNA of EGase was examined to see if it may play a role in this physiological disorder. Hemicellulosic fractions have also been analyzed since these have been found increasingly to undergo changes during ripening (Huber, 1983; McCollum et al., 1989; Seymour et al., 1990).

\section{Materials and Methods}

Fruit ASSESSMENTS. In total, 400 'Flavortop' nectarines were harvested from a commercial orchard in Kibbutz Rosh Tzurim on 15 July 1998, at a preclimacteric but physiologically mature stage of maturity, and selected for uniformity of size and ground color and freedom from defects and mechanical damage. The fruit were divided into two lots for storage with 50 fruit kept for assessment at harvest and after $5 \mathrm{~d}$ ripening at $20^{\circ} \mathrm{C}$. One lot of fruit was placed immediately at $0^{\circ} \mathrm{C}$ storage (control) and the second held for $2 \mathrm{~d}$ at $20^{\circ} \mathrm{C}$ and then stored at $0^{\circ} \mathrm{C}$ (delayed storage). Fruit firmness was determined on the opposite pared cheeks of each fruit with a HunterSpring penetrometer (Hatfield, Pa.) using an $11 \mathrm{~mm}$ tip. Plugs of tissue without peel were then taken from the fruit with a cork borer, and $2 \mathrm{~g}$ cylinder of flesh pushed through a $5 \mathrm{~mL}$ plastic syringe into a microfuge tube. The tube was weighed, centrifuged at $14,000 g_{n}$ and the juice and pulp weighed separately to determine percentage of expressed juice. The same fruit were cut in half and evaluated visually for woolly breakdown. Woolliness appeared as lack of juice on the cut surface and as tissue separation and discoloration when the disorder was more advanced. Five representative fruit were chosen for enzyme analysis and $50 \mathrm{~g}$ from each of these fruit were frozen for enzyme extraction and assay. Bulk samples (100 g) of flesh tissue from the remaining fruit were frozen in liquid nitrogen and freeze dried for RNA extraction.

ENZYME MEASUREMENTS. Frozen fruit flesh (40 g) was blended for $2 \mathrm{~min}$ in a homogenizer with $40 \mathrm{~mL}$ cold $12 \%$ polyethyleneglycol and $0.2 \%$ sodium bisulfite. The homogenate was centrifuged for $10 \mathrm{~min}$ at $13,000 \mathrm{~g}_{\mathrm{n}}$ and the pellet washed with $4{ }^{\circ} \mathrm{C}$ aqueous $0.2 \%$ sodium bisulfite. Pellets were divided into three equal parts and extracted for PE (EC 3.1.1.11), exo- and endo-PG (EC 3.2.1.67 and EC 3.2.1.15), andEGase (EC 3.2.1.4). For exo-PG and endo-PG, the pellet was incubated on a shaker at $4^{\circ} \mathrm{C}$ for $1 \mathrm{~h}$ in $15 \mathrm{~mL}$ cold $50 \mathrm{~mm}$ $\mathrm{Na}$ acetate buffer ( $\mathrm{pH}$ ) containing $0.5 \mathrm{M} \mathrm{NaCl}$. Following centrifugation as above, the supernatant was diluted $1: 1$ with $50 \mathrm{~mm} \mathrm{Na}$ acetate buffer at $\mathrm{pH} 5$ and used as crude extract. Exo-PG activity was determined according to Gross (1982). Enzyme extract $(0.15 \mathrm{~mL})$ was mixed with an equal volume of $0.5 \%$ polygalacturonic acid in $50 \mathrm{~mm} \mathrm{Na}$ acetate buffer ( $\mathrm{pH} 4.4)$, and incubated at $30^{\circ} \mathrm{C}$. Incubation was performed initially for $2,4,6$, and $18 \mathrm{~h}$ and found to be linear. For convenience, $18 \mathrm{~h}$ was the incubation time chosen. For determination of galacturonic acid released, $2 \mathrm{~mL}$ borate buffer $(0.1 \mathrm{M}, \mathrm{pH}$ 9.0) and $0.3 \mathrm{~mL} 1 \%$ cyanoacetimide were added to the reaction mixture, boiled $10 \mathrm{~min}$, cooled, and absorbency read at $274 \mathrm{~nm}$. Galacturonic acid was used as a standard, and controls of boiled extract were run in reaction buffer. One activity unit was $1 \mu \mathrm{g}$ galacturonic acid released per milligram protein per hour. Endo-PG activity was measured in a Cannon-Fenske viscosimeter (Munich, Germany) by mixing $3 \mathrm{~mL}$ enzyme extract with $4.5 \mathrm{~mL} 2 \%$ polygalacturonic acid in $50 \mathrm{~mm} \mathrm{Na}$ acetate (pH 4.4). Viscosity was measured immediately after adding enzyme extract and after $18 \mathrm{~h}$ incubation at $30^{\circ} \mathrm{C}$. One activity unit was the change in viscosity (in seconds) per unit protein per hour.

For PE extraction, the pellet was resuspended into $15 \mathrm{~mL} \mathrm{7.5 \%}$ (w/v) $\mathrm{NaCl}, 0.75 \%(\mathrm{w} / \mathrm{v})$ EDTA (pH 6.5), and incubated at $4{ }^{\circ} \mathrm{C}$ for $10 \mathrm{~min}$. Following centrifugation as above the supernatant was collected. Five mL crude extract was mixed with $20 \mathrm{~mL} 1 \%(\mathrm{w} / \mathrm{v})$ citrus pectin and titrated with $0.01 \mathrm{~mol} \cdot \mathrm{L}^{-1} \mathrm{NaOH}$ to maintain $\mathrm{pH} 7.4$ while incubating at $30^{\circ} \mathrm{C}$. The reaction was found to be linear for 2 $\mathrm{h}$, but normally the reaction was measured for $10 \mathrm{~min}$. One unit activity was calculated as $1 \mathrm{~mm} \mathrm{NaOH}$ consumed per mg protein per 10 min.

For EGase activity, the pellet was stirred in $15 \mathrm{~mL} 0.1 \mathrm{M}$ citrate phosphate buffer ( $\mathrm{pH} 6.0$ ), and $1 \mathrm{M} \mathrm{NaCl}$ at $4{ }^{\circ} \mathrm{C}$ for $1 \mathrm{~h}$, then centrifuged as above. Using the supernatant as crude extract, enzyme activity was measured by change in viscosity as for endoPG. The reaction mixture contained $6 \mathrm{~mL} 0.2 \%(\mathrm{w} / \mathrm{v})$ carboxy methyl cellulose (CMC) in citrate phosphate buffer and $3 \mathrm{~mL}$ of the supernatant. One activity unit was the change in viscosity (in seconds) per unit protein per hour. Protein content in the extracts was determined using Bio-Rad reagent (Hercules, Calif.).

RNA EXTRACTION AND NORTHERN BLOT ANALYSIS. Total RNA was extracted from $1 \mathrm{~g}$ of freeze-dried nectarine flesh by the method of Lopez-Gomez and Gomez-Lim (1992). RNA samples were separated on $1 \%$ agarose/formaldehyde gels and transferred to nitrocellulose (Schleicher \& Schuell, Munich, Germany). RNA blots were prehybridized and hybridized in formamide buffers at $42{ }^{\circ} \mathrm{C}$ as described by Sambrook et al., 1989. Final wash of the RNA blots was done in $0.5 \mathrm{XSSC}$, and $0.1 \% \mathrm{SDS}$ at $60^{\circ} \mathrm{C}$. Probes were labeled with ${ }^{32} \mathrm{P}$ by the random priming method, and included peach cDNAs of endo-PG and PE (gift of Diane Lester and Jim Speirs) and EGase (gift of Pietro Tonutti). To measure loading variations blots were rehybridized with the $25 \mathrm{~S}$ rRNA gene probe (gift of Mihaly Kis).

Cell wall eXtraction AND ANALYSIS. Cell wall material (CWM) was extracted from $5 \mathrm{~g}$ frozen fruit flesh in boiling ethanol for 20 min, the ethanol was decanted by filtration, and the solid residue transferred to $20 \mathrm{~mL}$ distilled water with $0.02 \%$ sodium azide. The tissue was ground by Turrax and then centrifuged at $15,000 g_{\mathrm{n}}$ for 10 min. Supernatant was collected and filtered as water-soluble fraction. The pellet was washed with acetone and then with 1 chloroform : 1 methanol $(\mathrm{v} / \mathrm{v})$. The pellet was resuspended in $20 \mathrm{~mL} 50 \mathrm{~mm}$ trans-1,2-diaminocyclohexane-N,N,N',N'-tetraacetic acid(CDTA), shaken for $3 \mathrm{~h}$, and centrifuged at $15,000 \mathrm{~g}_{\mathrm{n}}$ for $10 \mathrm{~min}$. The supernatant was collected and the pellet was extracted twice more with $20 \mathrm{~mL} \mathrm{CDTA}$. The three supernatants were combined as the CDTA fraction. The pellet was resuspended in $20 \mathrm{~mL} 50 \mathrm{~mm}$ $\mathrm{Na}_{2} \mathrm{CO}_{3}, 20 \mathrm{~mm} \mathrm{NaBH}_{4}$ at $4{ }^{\circ} \mathrm{C}$ for $18 \mathrm{~h}$ plus $2 \mathrm{~h}$ at RT, centrifuged at $15,000 \mathrm{~g}_{\mathrm{n}}$ for $10 \mathrm{~min}$, and the supernatant adjusted to $\mathrm{pH} 7.0$ with acetic acid. This was the carbonate-soluble fraction. The pellet was resuspended in $20 \mathrm{~mL} 6 \mathrm{M}$ guanidine thiocyanate (GTC) for $20 \mathrm{~h}$, centrifuged as above and the supernatant collected. All fractions were dialyzed in $3500 \mathrm{Mr}$ cut-off tubing and then lyophilized.

Each fraction was redissolved in $0.5 \mathrm{~mL} 0.2 \mathrm{M}$ imidazole $(\mathrm{pH}$ 6.8), and an $0.05 \mathrm{~mL}$ aliquot was resolved on high-performance liquid chromatography (HPLC) using a Bio-Sil SEC-400-5 column (Bio-Rad). The same imidazole buffer was used as a mobile phase at a flow rate $0.3 \mathrm{~mL} \cdot \mathrm{min}^{-1}$. Dextrans of $2000,488,76$, and $29 \mathrm{ku}$ were used as Mr markers. Fractions were analyzed for uronic acid using the m-hydroxydiphenol method (Blumenkranz and AsboeHansen, 1973) or for neutral sugars using the anthrone method (Dische, 1962). Standard curves were plotted using galacturonic 

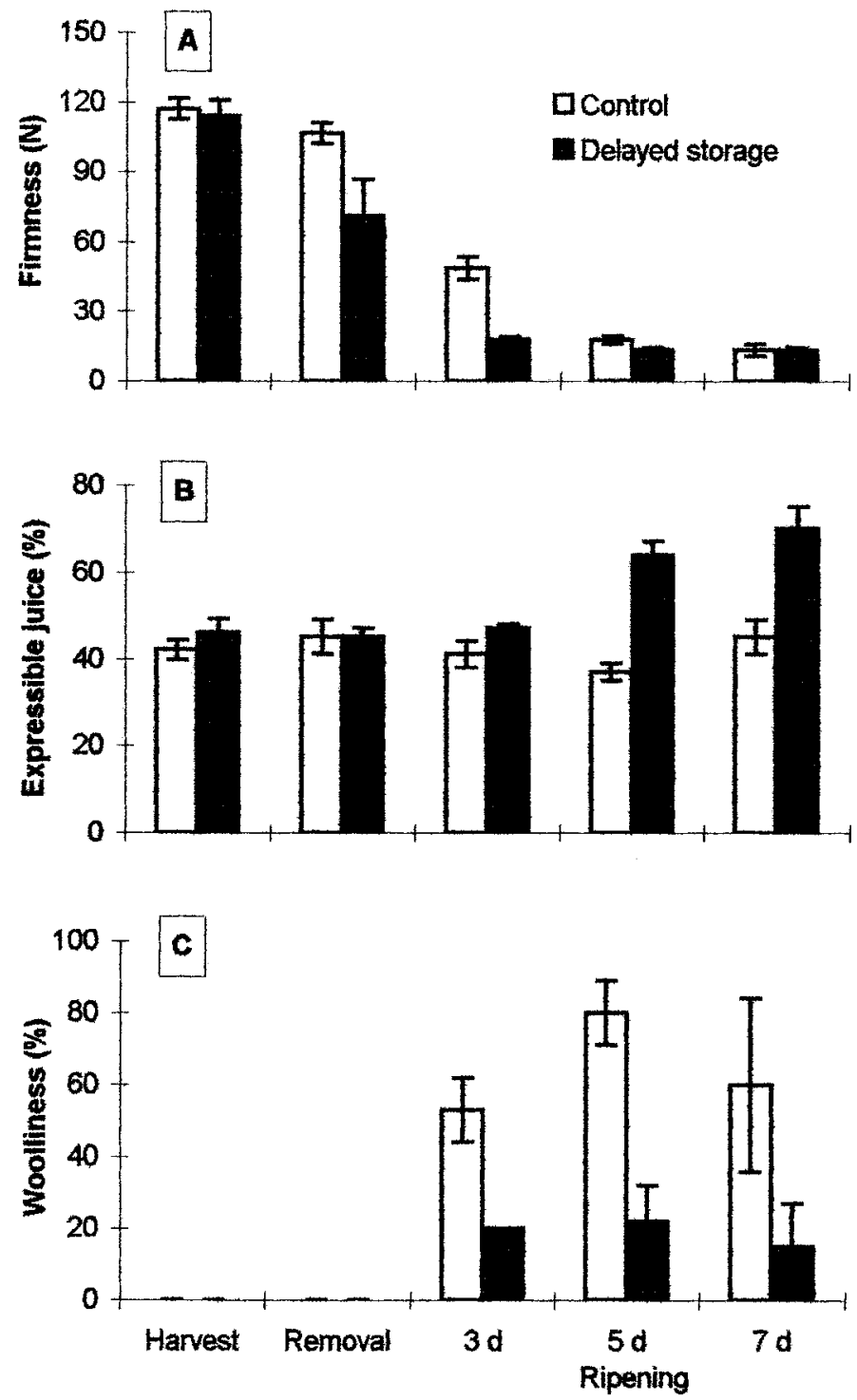

Fig. 1. Ripening of control and delayed storage fruit at $20^{\circ} \mathrm{C}$ for $7 \mathrm{~d}$ following 4 weeks of $0^{\circ} \mathrm{C}$ storage. (A) Firmness decrease, (B) increase in expressible juice in fruit flesh, and $(\mathbf{C})$ development of woolliness in the flesh. Vertical lines represent standard deviation.

acid (for the m-hydroxydiphenol method) and glucose (for the anthrone method).

An aliquot of each fraction was also derivatized to alditol acetates and analyzed by gas chromatography for neutral sugar composition (Albersheim et al., 1967; Blakeney et al., 1983). Samples were injected into gas chromatograph with DB-225 capillary column (Supelco, Bellefonte, Pa.) and a flame ionization detector run isothermally at $210^{\circ} \mathrm{C}$ using He as carrier gas. Peaks were quantified against an inositol internal standard added to the sample before derivitization.

\section{Results}

FruIT RIPENING. Fruit were harvested at $117 \mathrm{~N}$ firmness and had $42 \%$ expressible juice (Fig. 1). During a 5 d ripening period at $20^{\circ} \mathrm{C}$ without cold storage, the fruit ripened normally and softened to 26 $\mathrm{N}$ firmness and expressible juice increased to $59 \%$. During the $2 \mathrm{~d}$ of delayed storage at $20{ }^{\circ} \mathrm{C}$ the firmness loss was only $3 \mathrm{~N}$, while expressible juice increased to $46 \%$. Following 4 weeks of $0{ }^{\circ} \mathrm{C}$ storage the control fruit had decreased to $106 \mathrm{~N}$ firmness, while the delayed storage fruit softened to $71 \mathrm{~N}$. During ripening following storage, there were major woolliness and expressible juice differences between the fruit from the two treatments in addition to firmness differences.

The delayed-storage fruit decreased in firmness during the first $3 \mathrm{~d}$ at $20^{\circ} \mathrm{C}$ to their final softness, while the control fruit took $5 \mathrm{~d}$ to soften completely. During softening, the amount of expressible juice increased in the fruit of delayed storage, while decreasing in the control fruit during the first $5 \mathrm{~d}$ of ripening, and on day 7 returning to the amount of expressible juice which was present at removal from storage, when the fruit were very firm. The decrease in expressible juice in the control fruit was a mirror image of the increase in visible woolliness present in the flesh of the fruit; increasing during the first $5 \mathrm{~d}$ at $20^{\circ} \mathrm{C}$ and then decreasing slightly at longer times of ripening. About $20 \%$ of delayed-storage fruit had slight signs of woolliness and the rest had healthy, juicy flesh.

mRNA. PG mRNA was nondetectable at harvest, but increased greatly during ripening (Fig. 2). After $0^{\circ} \mathrm{C}$ storage, message level was higher than at harvest in both control fruit and delayed-storage fruit and increased further during ripening. PG message abundance in the delayed-storage fruit following storage was higher than in control fruit, but after ripening they were similar. PE mRNA, on the other hand, was abundant at harvest and decreased during ripening. In contrast, it was low at the end of $0{ }^{\circ} \mathrm{C}$ storage, though lower in delayed-storage fruit than in control fruit, and increased during ripening after storage. There was no effect of delayed storage on the mRNA of PE after storage and the increase during ripening after storage was similar in fruit from both treatments. EGase message was very low at harvest and the only point where the message increased was in the control fruit after $0^{\circ} \mathrm{C}$ storage and ripening, while in delayed-storage fruit the message was still very low.

Cell wall enzymes. Delayed-storage fruit had higher exo-PG activity at the beginning of storage than control fruit, but the $2 \mathrm{~d}$ at $20{ }^{\circ} \mathrm{C}$ did not affect the enzyme activities of the other cell wall hydrolyzing enzymes (Fig. 3). At the end of storage, endo-PG activity was lower in control fruit than in delayed-storage fruit. Activity of exo-PG was not significantly higher in the delayedstorage fruit compared to control fruit. During ripening, activities of both enzymes increased in fruit from both treatments. Exo-PG activity after ripening was higher in delayed-storage fruit than in control fruit, but the endo-PG activity of fruit from both treatments

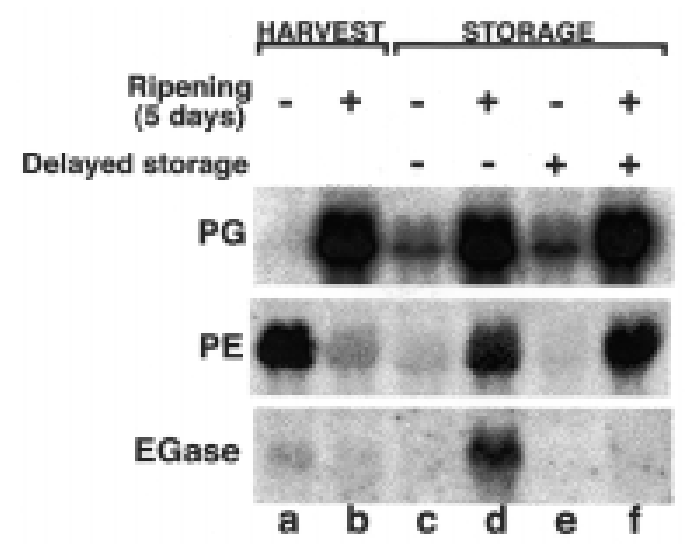

Fig. 2. Detection of PG, PE, and EGase mRNA in nectarine RNA. Lanes: $a=$ freshly harvested fruit, $\mathrm{b}=$ harvested fruit held $5 \mathrm{~d}$ at $20^{\circ} \mathrm{C}$ for ripening, $\mathrm{c}=$ control fruit after 4 weeks $0{ }^{\circ} \mathrm{C}$ storage, $\mathrm{d}=$ control fruit after $5 \mathrm{~d}$ at $20^{\circ} \mathrm{C}, \mathrm{e}=$ delayed storage fruit after 4 weeks $0{ }^{\circ} \mathrm{C}$ storage, and $\mathrm{f}=$ delayed storage fruit after $5 \mathrm{~d}$ at $20^{\circ} \mathrm{C}$. 

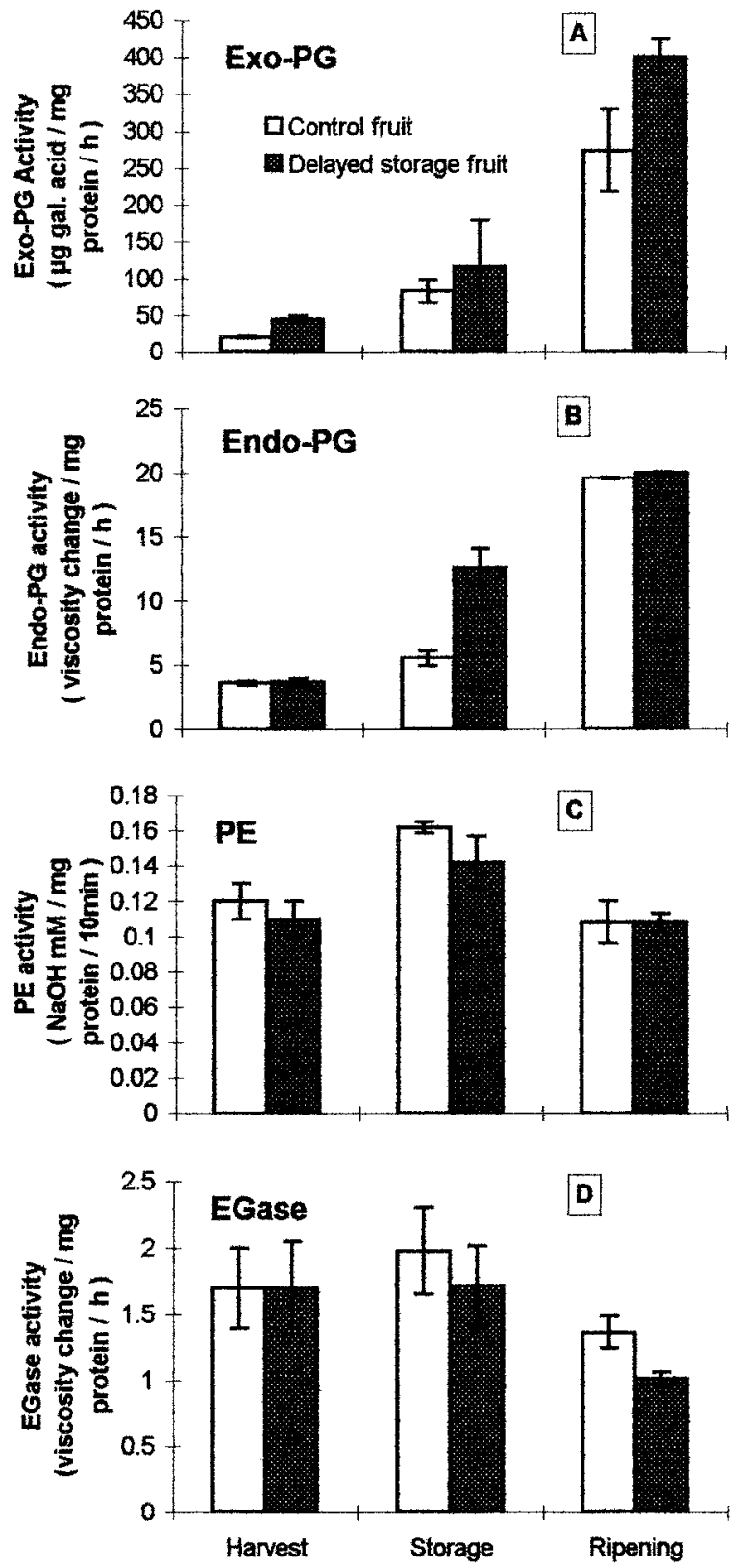

Fig. 3. Activity of cell wall hydrolyzing enzymes without storage, after 4 weeks of $0{ }^{\circ} \mathrm{C}$ storage, and after 5 additional days of ripening at $20^{\circ} \mathrm{C}$. (A) Exo-PG, (B) endo-PG, (C) PE, and (D) EGase activity. Vertical lines represent standard deviation. was similar. PE activity was higher after cold storage than it was after ripening. At removal from storage, it was higher in control fruit than in delayed-storage fruit, but after ripening activity was similar in fruit from both treatments. EGase activity also decreased during ripening. It was higher after ripening in control fruit than in delayedstorage fruit.

Cell wall Polymers. Uronic acid contents of the water soluble fraction increased during ripening, both after harvest and after $0{ }^{\circ} \mathrm{C}$ storage (Table 1). Neutral sugars were less consistent, decreasing during ripening both in freshly harvested fruit and in control fruit, and increasing in delayed-storage fruit. The ratios of uronic acid to neutral sugars in this fraction increased during ripening. In this fraction between $50 \%$ to $70 \%$ of the neutral sugars were glucose (Table 2), which was in polymers of low Mr not associated with uronic acid, as determined by HPLC analysis (data not presented). The decrease in neutral sugars during ripening may reflect further degradation of the glucose and its use as a metabolite.

The amount of CDTA soluble uronic acid was similar in nonstored and $0{ }^{\circ} \mathrm{C}$ stored fruit, and decreased between 3 and 5 fold as the fruit ripened (Table 1). There were very few neutral sugars associated with this fraction and they, too, decreased as the fruit ripened. The major neutral sugar was arabinose, followed by galactose, and rhamnose (Table 2). There were no major differences among the various treatments.

At harvest or after $0^{\circ} \mathrm{C}$ storage, the amount of uronic acid found in the carbonate-soluble fraction was similar to that in the watersoluble fraction, except in the case of delayed storage where more was found in the water-soluble fraction (Table 1). This probably reflects the fact that these fruit were softer at the end of $0{ }^{\circ} \mathrm{C}$ storage, though not softer before storage. However, during ripening delayedstorage fruit lost $75 \%$ to $80 \%$ of their uronic acids, while control fruit lost only $60 \%$. This was the major difference found between healthy (harvest and delayed storage) and woolly (control) fruit; a retention of uronic acid in this fraction of control fruit during ripening. Galactose was lower in fruit after $0{ }^{\circ} \mathrm{C}$ storage than in fruit ripened after harvest, while arabinose decreased during ripening after harvest and delayed storage, but not in control fruit (Table 2).

The guanidine thiocyanate (GTC)-soluble hemicellulosic fraction contained $\approx 30 \%$ uronic acid (Table 1 ). Both the uronic acid and neutral sugar components decreased during ripening. We presume that most of this pectin resembling carbohydrate was left behind following the sodium bicarbonate extraction step. The major neutral sugars were glucose, xylose, arabinose, and galactose (Table 2). The latter two may be associated mainly with the uronic acid remaining in this fraction.

The Mr distribution of CDTA-, sodium carbonate-, and GTCsoluble fractions are illustrated in Fig. 4 and 5. The water-soluble

Table 1. Uronic acid (UA) and neutral sugar (NS) contents ( $\mathrm{mg} \cdot \mathrm{g}^{-1}$ fresh weight $\pm \mathrm{SD}$ ) and the ratios between them in three pectic [water, trans-1,2-diaminocyclohexane$\mathrm{N}, \mathrm{N}, \mathrm{N}^{\prime}, \mathrm{N}^{\prime}$-tetraacetic acid (CDTA), and sodium carbonate] fractions and one hemicellulose [guanidine thiocyanide (GTC)] fraction from cell walls of nectarines at harvest and after cold storage and $5 \mathrm{~d}$ of ripening at $20^{\circ} \mathrm{C}$

\begin{tabular}{|c|c|c|c|c|c|c|c|c|c|c|c|c|}
\hline \multirow[b]{2}{*}{ Treatment } & \multicolumn{3}{|c|}{ Water } & \multicolumn{3}{|c|}{ CDTA } & \multicolumn{3}{|c|}{ Sodium carbonate } & \multicolumn{3}{|c|}{ GTC } \\
\hline & UA & NS & Ratio & UA & NS & Ratio & UA & NS & Ratio & UA & NS & Ratio \\
\hline At harvest & $16.0 \pm 0.20$ & $68.2 \pm 3.76$ & 0.23 & $13.6 \pm 1.59$ & $2.2 \pm 0.14$ & 6.18 & $18.7 \pm 1.19$ & $5.8 \pm 0.09$ & 3.22 & $3.7 \pm 0.04$ & $7.1 \pm 0.17$ & 0.52 \\
\hline \multicolumn{13}{|l|}{ After storage } \\
\hline Control & $18.5 \pm 0.63$ & $105.9 \pm 0.14$ & 0.17 & $14.3 \pm 0.05$ & $2.9 \pm 0.08$ & 4.93 & $19.7 \pm 0$ & $5.2 \pm 0$ & 3.78 & $3.5 \pm 0.10$ & $6.9 \pm 0.29$ & 0.50 \\
\hline Delayed storage & $22.2 \pm 1.96$ & $76.2 \pm 1.29$ & 0.29 & $11.3 \pm 0.29$ & $1.6 \pm 0.06$ & 7.06 & $13.2 \pm 0.61$ & $3.4 \pm 0.13$ & 3.88 & $1.7 \pm 0.49$ & $4.3 \pm 1.05$ & 0.39 \\
\hline Ripening after harvest & $29.1 \pm 2.77$ & $58.1 \pm 1.35$ & 0.50 & $3.3 \pm 0.14$ & $1.1 \pm 0.06$ & 3.0 & $4.5 \pm 0.33$ & $1.8 \pm 0.18$ & 2.50 & $1.8 \pm 0.02$ & $4.4 \pm 0.18$ & 0.40 \\
\hline \multicolumn{13}{|l|}{ Ripening after storage } \\
\hline Control & $34.7 \pm 1.48$ & $97.2 \pm 2.68$ & 0.35 & $4.9 \pm 0.72$ & $1.9 \pm 0.18$ & 2.57 & $8.4 \pm 0.98$ & $2.5 \pm 0.28$ & 3.36 & $1.9 \pm 0.10$ & $5.7 \pm 0.11$ & 0.33 \\
\hline Delayed storage & $42.8 \pm 0.60$ & $129.5 \pm 2.43$ & 0.33 & $2.0 \pm 0$ & $0.9 \pm 0.06$ & 2.22 & $2.8 \pm 0.15$ & $0.9 \pm 0.04$ & 3.11 & $1.2 \pm 0.01$ & $4.8 \pm 0.05$ & 0.25 \\
\hline
\end{tabular}


Table 2. Neutral sugar composition of three pectic [water, trans-1,2-diaminocyclohexane-N,N,N',N'-tetraacetic acid (CDTA), and sodium carbonate] fractions and one hemicellulose [guanidine thiocyanide (GTC)] fraction of cell wall material from nectarines at harvest (nonstored) and after cool storage and $5 \mathrm{~d}$ of ripening at $20^{\circ} \mathrm{C}$.

\begin{tabular}{|c|c|c|c|c|c|c|c|}
\hline \multirow[b]{2}{*}{ Fraction } & \multicolumn{7}{|c|}{ Composition (mol \%) } \\
\hline & Rhamnose & Fucose & Arabinose & Xylose & Mannose & Galactose & Glucose \\
\hline \multicolumn{8}{|l|}{ Water soluble } \\
\hline Harvest & 2.5 & 0.9 & 9.8 & 3.8 & 6.6 & 7.3 & 68.9 \\
\hline Control & 3.2 & 1.3 & 9.4 & 3.8 & 3.7 & 7.0 & 71.4 \\
\hline Delayed storage & 5.1 & 1.7 & 15.5 & 3.1 & 3.9 & 7.5 & 63.1 \\
\hline Ripening after harvest & 4.9 & 1.7 & 19.8 & 4.6 & 2.9 & 10.2 & 55.6 \\
\hline Storage control & 3.5 & 1.2 & 13.8 & 5.1 & 5.5 & 7.5 & 62.3 \\
\hline Delayed storage & 5.1 & 1.5 & 16.2 & 6.3 & 8.5 & 7.8 & 57.1 \\
\hline \multicolumn{8}{|l|}{ CDTA } \\
\hline Harvest & 12.2 & 2.8 & 56.3 & 4.5 & 3.2 & 17.2 & 3.4 \\
\hline Control & 7.5 & 9.0 & 54.9 & 6.1 & 3.5 & 13.2 & 5.6 \\
\hline Delayed storage & 6.4 & 10.6 & 54.8 & 5.8 & 3.8 & 12.7 & 5.6 \\
\hline Ripening after harvest & 9.3 & 2.3 & 58.9 & 4.7 & 3.4 & 17.2 & 3.9 \\
\hline Storage control & 12.3 & 3.5 & 54.8 & 5.7 & 2.6 & 18.7 & 6.4 \\
\hline Delayed storage & 10.2 & 2.8 & 47.8 & 6.0 & 7.7 & 15.8 & 8.2 \\
\hline \multicolumn{8}{|l|}{ Sodium carbonate } \\
\hline Harvest & 9.4 & 1.5 & 57.1 & 3.0 & 3.2 & 22.3 & 3.2 \\
\hline Control & 10.2 & 1.9 & 60.8 & 3.6 & 3.4 & 14.8 & 5.0 \\
\hline Delayed storage & 10.4 & 1.9 & 59.1 & 3.4 & 3.7 & 14.6 & 6.5 \\
\hline Ripening after harvest & 8.8 & 2.1 & 54.5 & 4.8 & 3.8 & 21.2 & 4.6 \\
\hline Storage control & 11.7 & 2.4 & 63.1 & 4.2 & 0.6 & 13.9 & 3.8 \\
\hline Delayed storage & 10.2 & 2.9 & 53.8 & 6.6 & 1.8 & 15.3 & 9.0 \\
\hline \multicolumn{8}{|l|}{ GTC } \\
\hline Harvest & 4.0 & 5.3 & 25.7 & 19.9 & 6.9 & 18.8 & 19.2 \\
\hline Control & 4.2 & 5.5 & 25.6 & 18.4 & 9.4 & 15.7 & 21.1 \\
\hline Delayed storage & 4.0 & 7.0 & 22.3 & 21.6 & 8.9 & 14.7 & 21.4 \\
\hline Ripening after harvest & 2.7 & 6.1 & 16.0 & 24.2 & 10.6 & 16.8 & 21.3 \\
\hline Storage control & 3.6 & 5.9 & 18.8 & 22.0 & 10.6 & 15.6 & 23.1 \\
\hline Delayed storage & 2.8 & 6.9 & 12.7 & 23.5 & 11.4 & 16.6 & 25.7 \\
\hline
\end{tabular}

Fig. 4. Uronic acid containing polymers from an HPLC fractionation column. (A) CDTAsoluble fraction at harvest and following $0{ }^{\circ} \mathrm{C}$ storage, and (B) after ripening. (C) Carbonatesoluble fraction at harvest and following $0{ }^{\circ} \mathrm{C}$ storage, and (D) after ripening.
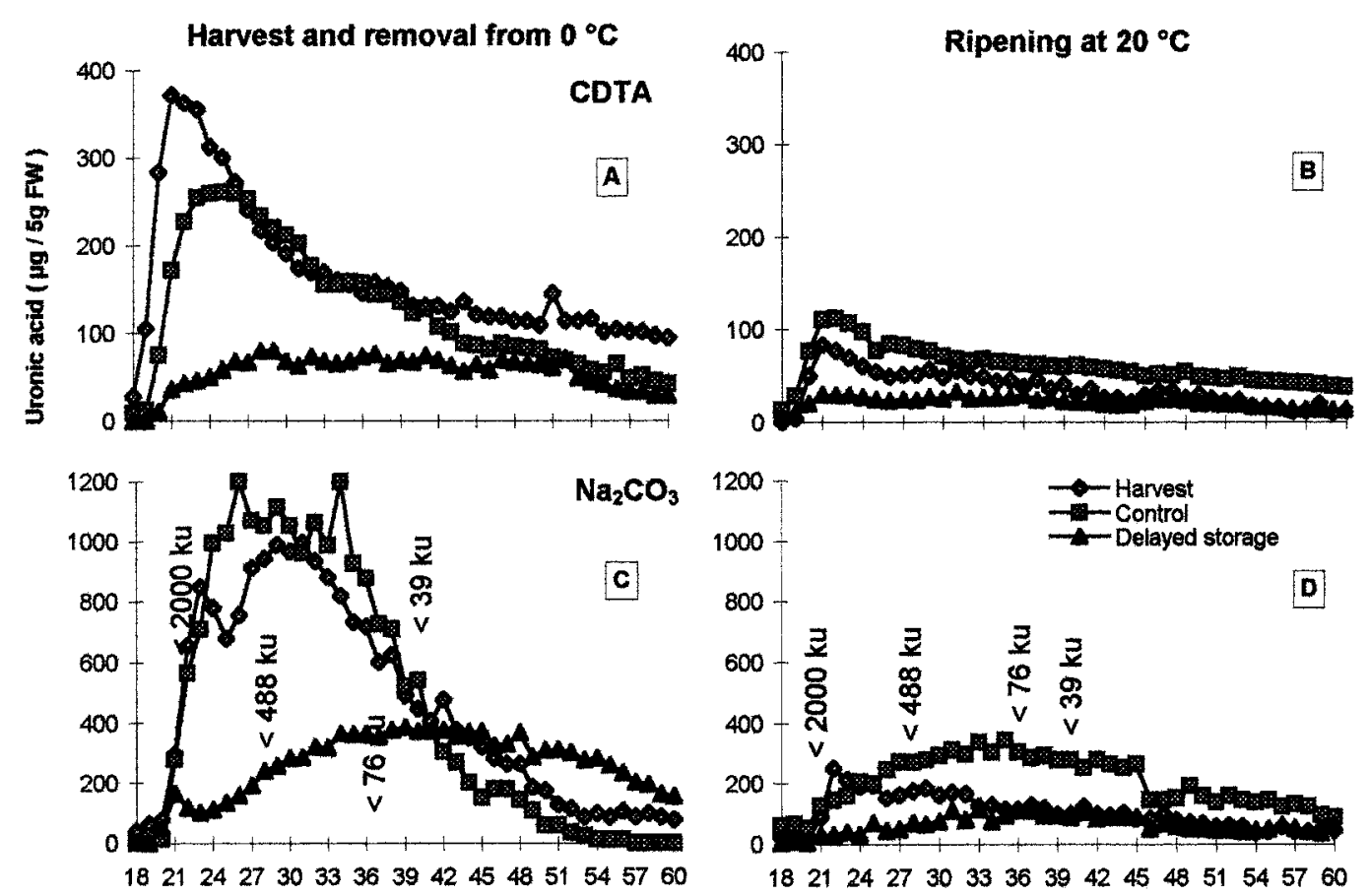

Fraction number 

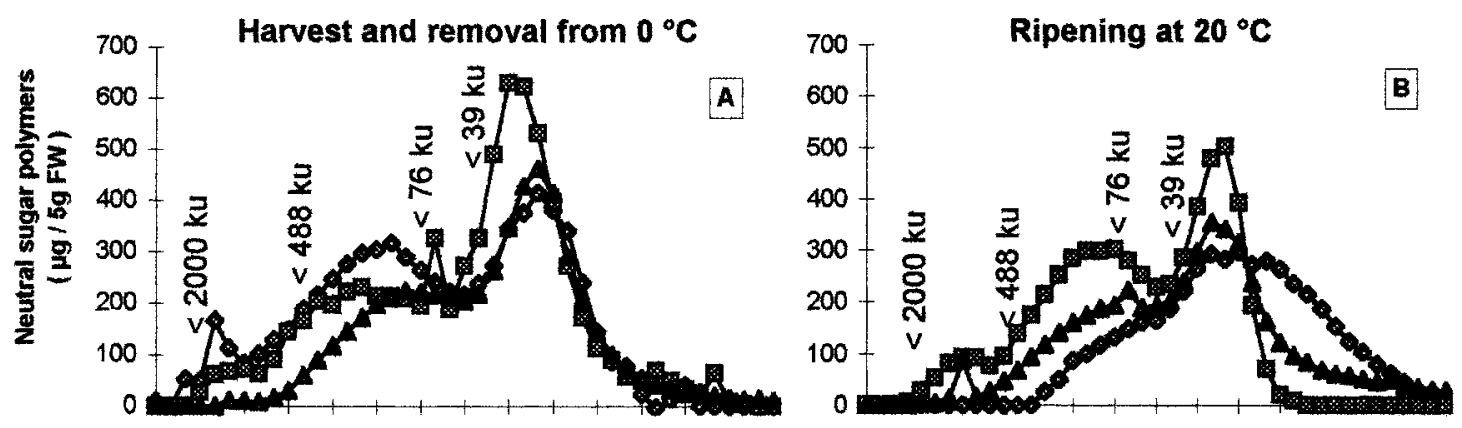

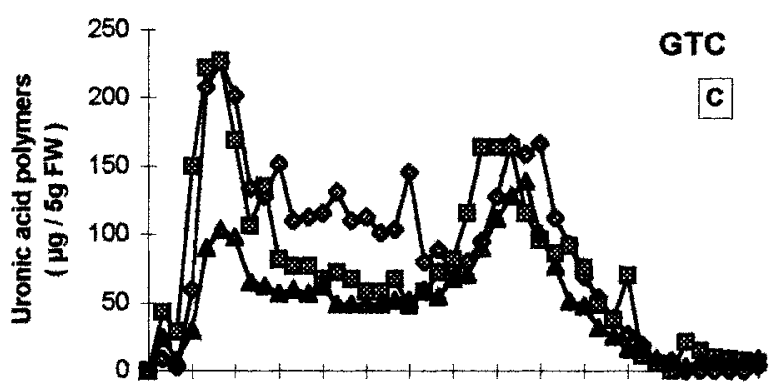

$\begin{array}{lllllllllllllll}18 & 21 & 24 & 27 & 30 & 33 & 36 & 39 & 42 & 45 & 48 & 51 & 54 & 57 & 60\end{array}$

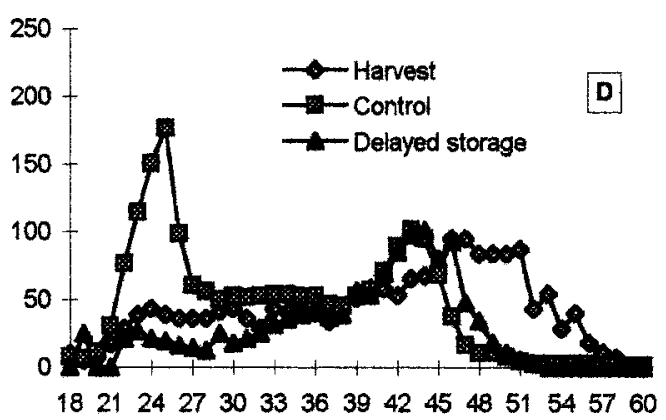

Fig. 5. Neutral sugar and uronic acid containing polymers from HPLC fractionation of the guanidine thiocyanate (GTC)soluble fraction. (A) Hemicellulose polymers after harvest and following cold storage and (B) after ripening. (C) Pectin poly-mers at harvest and after cold storage and (D) after ripening.

\section{Fraction number}

fraction showed one major peak for neutral sugars below $70 \mathrm{ku}$ and a second even smaller for uronic acids, with no difference found between healthy and woolly fruit in the size of these peaks (data not presented). On the other hand, there were major differences in the peak distribution and size of the other fractions from woolly and healthy fruit. In both the CDTA- and carbonate-soluble fractions, fruit ripened after harvest and control fruit after $0{ }^{\circ} \mathrm{C}$ storage had a preponderance of high $\mathrm{Mr}$ uronic acid containing polymers, although the carbonate-soluble fraction polymers were much more heterogenous in size (Fig. 4A and C). In contrast, the delayedstorage fruit in both fractions contained uronic acid containing polymers which were shifted to a lower Mr with no clear peak. Following $5 \mathrm{~d}$ of ripening, the large peaks in the harvest and control fruit CDTA and carbonate-soluble fractions had decreased, and all fruit from all three treatments were more similar in the size distribution of the pectic polymers. However, in both fractions, but particularly in the carbonate fraction, the control fruit contained more polymeric material. After ripening, the control fruit carbonate fraction was similar to the profile of pectin polymers found in delayed-storage fruit following $0{ }^{\circ} \mathrm{C}$ storage (Fig. 4C and D).

The hemicellosic neutral sugar fraction solubilized by GTC showed two distinct peaks, one between the 480 and $76 \mathrm{ku} \mathrm{Mr}$, and a second below $39 \mathrm{ku}$ (Fig. 5A). At removal from storage, control fruit contained most of the polymers in the small Mr peak. After ripening, harvested fruit and delayed-storage fruit had similar profiles, with the large peak very indistinct, while the control fruit still showed two distinct peaks.

The pectic material of harvest fruit associated with this fraction had a number of peaks spread throughout the Mr range (Fig. 5C). The highest Mr peak was similar to that in the CDTA fraction, and the smallest was in the same Mr range as the small hemicellulose peak of this fraction. After cold storage, control fruit retained the high and low peaks, but lost the intermediate ones, while delayedstorage fruit had a greatly reduced high $\mathrm{Mr}$ peak. Following ripening, the high $\mathrm{Mr}$ peak had disappeared from all except the control fruit, and the pectin polymers were smallest in the harvest fruit (Fig. 5D).

\section{Discussion}

Delaying storage of nectarines effectively prevents development of woolliness after $0{ }^{\circ} \mathrm{C}$ storage and allows the fruit to develop characteristic juiciness found in ripe nectarines. In control fruit which were placed directly in $0^{\circ} \mathrm{C}$ storage, softening occurred when returned to $20^{\circ} \mathrm{C}$ for ripening, but juiciness did not develop in many fruit. In these fruit the appearance of woolliness was inversely related to the amount of expressible juice found in the fruit (Fig. 1). This is an indication that the juice in woolly fruit is being bound by some cellular components and cannot be released by the juicing procedure. This measurement imitates homogenization of fruit tissue during mastication, and therefore, less juice would mean a dry, woolly texture while eating. Harker and Southerland (1993) measured cell separation of nectarines during ripening. They found woolly and nonwoolly (healthy) fruit adhesion between cells decreased, turgor decreased, and the propensity of cells to rupture increased as fruit softened. However, in scanning electron micrographs of woolly fruit there was an absence of juice on the cell wall fracture surface after tensile tests, and a higher percentage of air space compared to healthy fruit. Apparently in woolly fruit, the juice is being absorbed by the cell walls while in healthy fruit it is present on the surface and easily extractable.

Delayed storage appears to prevent woolliness by allowing softening to continue, albeit slowly, during $0{ }^{\circ} \mathrm{C}$ storage. The $2 \mathrm{~d}$ at $20^{\circ} \mathrm{C}$ did not cause firmness loss at the time, but these fruit softened more during storage than control fruit. Control fruit lost $12 \%$ of their initial firmness during storage, while the delayed-storage fruit lost $40 \%$ (Fig. 1). This difference in firmness was reflected by the differences in cell wall components of delayed-storage fruit compared to both harvested and control fruit. In both the CDTA- and sodium carbonate-soluble pectin fractions, the depolymerization of the polymers was extensive in delayed-storage fruit upon removal from $0{ }^{\circ} \mathrm{C}$, which was not the case for control fruit (Fig. 4). There was also a shift in the pectin material, with less UA in the CDTA- and soldium carbonate-soluble and more UA in the water-soluble fraction of fruit from this treatment (Table 1). After $0{ }^{\circ} \mathrm{C}$ storage, 
delayed-storage fruit had less hemicellulosic material, which was reflected mainly in loss of high $\mathrm{Mr}$ fractions (Fig. 5).

Changes in cell wall components and their relation to normal ripening in delayed-storage fruit is reminiscent of changes found in fruit from intermittent warming; i.e., removal of the fruit at regular intervals from $0{ }^{\circ} \mathrm{C}$ storage, held for $1 \mathrm{~d}$ at $20^{\circ} \mathrm{C}$, and then recooled (Anderson, 1979; Anderson and Penney, 1975; Ben-Arie et al., 1970; Lill, 1985). Nectarines subjected to intermittent warming softened significantly during storage, but exhibited little woolliness (Dawson et al., 1995).

This mechanism for preventing woolliness during ripening after storage is in contrast to what was found in fruit from controlled atmosphere. Holding nectarines in controlled atmosphere can delay the development of woolliness (Anderson, 1982; Lurie, 1992; Tonini et al., 1989). But these fruit do not soften during storage, and the cell wall components remain very similar to fruit at harvest (Lurie et al., 1994). However, fruit from controlled atmosphere storage retain their ability to soften and degrade the cell wall polymers following storage, thus providing a healthy, juicy fruit.

Activities of cell wall hydrolyzing enzymes, which are presumably responsible for the changes in the size and composition of the pectic and hemicellulosic polymers, are rather similar in control and delayed-storage fruit following storage. Exceptions were that exo$\mathrm{PG}$ of delayed-storage fruit was higher entering $0^{\circ} \mathrm{C}$ storage, while at the end of storage endo-PG activity of delayed storage fruit was more than double that of control fruit. This higher activity of endoPG corresponds with the large difference in Mr profiles of CDTAand $\mathrm{Na}_{2} \mathrm{CO}_{3}$-soluble pectins from delayed storage compared to control fruit. Activity of PE in delayed-storage fruit was slightly lower than in control fruit at the end of $0{ }^{\circ} \mathrm{C}$ storage, while the differences in the other two enzymes (low exo-PG and high EGase) were not significant between the treatments. The activity of PE in removing methyl groups from galacturonic acid is thought to be necessary to allow endo-PG access to the pectin backbone (BenArie et al., 1989; Pressey and Avants, 1973). However, it appears that in fruit from both delayed storage and control treatments, the activity of $\mathrm{PE}$ was retained during $0^{\circ} \mathrm{C}$ storage, and would not be an impediment to pectin degradation.

The activity measured for the hydrolytic enzymes bears little relation to the abundance of their respective mRNAs. Endo-PG, whose activity was higher in delayed-storage fruit at the beginning of ripening, showed similar message levels as in control fruit. The message does, however, increase during ripening as does enzyme activity in both treatments. In contrast, PE message was low at the end of $0{ }^{\circ} \mathrm{C}$ storage when activity is high and increased during ripening as activity was declining. What is more interesting is that at harvest, the message was very high and decreased as the fruit ripened. Harvested fruit had lower PE activity before ripening following storage (Ben-Arie and Sonego, 1980). The message abundance of this enzyme appeared to be in inverse relationship to its measurable activity. It is possible that the PE protein is quite stable at low temperatures, and less so at $20^{\circ} \mathrm{C}$. Therefore, at $0{ }^{\circ} \mathrm{C}$ less message would be needed than at ambient temperature to retain enzyme activity. This supposition is supported by the observation that activity does not decrease at $0{ }^{\circ} \mathrm{C}$, but increases as time at $0{ }^{\circ} \mathrm{C}$ is extended (Ben-Arie and Sonego, 1980; Von Mollendorff and De Villiers, 1988).

Message of EGase was low in fruit at all times measured, except in control fruit at the end of ripening. This is in stark contrast to the enzyme activity which was high at removal from $0{ }^{\circ} \mathrm{C}$ storage and decreased during ripening in all fruit. Endo-glucanase transcripts in peach were generally detectable only after amplification of the total
RNA by RT-PCR (Bonghi et al., 1998). This may be why in this study low hybridization levels were generally found. The increase in abundance following storage was not examined previously, and the large increase in mRNA in woolly fruit was unexpected. Our data corroborates that EGases are involved in the initial phases of fruit softening (Bonghi et al., 1998; Hinton and Pressey, 1974), since activity decreases in the later stages of fruit softening. However, even with similar activities seen in EGase in control and delayedstorage fruit, the loss of hemicellulose and the changes in polymer size were much less in control than in delayed-storage fruit. The doubling of the NS content in the water soluble fraction during storage of control fruit and during ripening of delayed-storage fruit (Table 1), with most of the sugars being glucose (Table 2), may be related to EGase activity. However, this does not appear to be related to development of woolliness, but simply to extended storage.

The hypothesis that development of woolliness in nectarines is due to an imbalance in the activities of PG and PE following cold storage is supported by this study, but it is clearly not the whole story. Control fruit had lower PG and higher PE activity than delayedstorage fruit following $0{ }^{\circ} \mathrm{C}$ storage, and this was reflected in differences in the pectin content and $\mathrm{Mr}$ of the CDTA- and $\mathrm{Na}_{2} \mathrm{CO}_{3}$ soluble fractions. However, there were also changes occurring in the hemicellulose fraction during ripening which did not occur in the control fruit and this may make a contribution to woolliness. In addition, an assumption that the lack of PG activity was due to inhibition of enzyme synthesis does not appear to be correct. The mRNA for endo-PG was similar in fruit from both treatments. Protein presence as measured by Western blotting was also similar in fruit which ripened normally with high PG activity or which developed woolliness and had low PG activity (Sonego, et al., 1999). Therefore, some form of enzyme activation or inhibition may be involved in the differences found in PG activity following cold storage and in the pectin substrates in healthy compared to woolly fruit.

\section{Literature Cited}

Albersheim, P., D. Nevins, P., English, and A. Karr. 1967. A method for analysis of sugars in plant-cell wall polysaccharides by gas-liquid chromatography. Carbohydrate Res. 5:340-345.

Anderson, R.E. 1979. The influence of storage temperature and warming during storage on peach and nectarine fruit quality. J. Amer. Soc. Hort. Sci. 104:459-461.

Anderson, R.E. 1982. Long-term storage of peaches and nectarines intermittently warmed during controlled-atmosphere storage. J. Amer. Soc. Hort. Sci. 107:214-216.

Anderson, R.E. and R.W. Penney. 1975. Intermittent warming of peaches and nectarines stored in controlled atmosphere or air. J. Amer. Soc. Hort. Sci. 100:151-153.

Ben-Arie, R. and S. Lavee. 1971. Pectic changes occurring in 'Elberta' peaches sufferering from woolly breakdown. Phytochemistry 10:531538.

Ben-Arie, R., S. Lavee, and S. Guelfat-Reich. 1970. Control of woolly breakdown of 'Elberta' peaches in cold storage by intermittent exposure to room temperature. J. Amer. Soc. Hort. Sci. 95:801-803.

Ben-Arie, R. and L. Sonego. 1980. Pectolytic enzyme activity involved in woolly breakdown of stored peaches. Phytochemistry 19:2553-2555.

Ben-Arie, R., S. Sonego, M. Zeidman, and S. Lurie. 1989. Cell separation during fruit ripening, p. 253-260. In:D. Osborne and M.B. Jackson (eds.). Cell separation in plants. Springer-Verlag, Berlin.

Blakeney, A.B., P.J. Harris, R.J.Henry, and B.A. Stone. 1983. A simple and rapid preparation of alditol acetates for monosaccharide analysis. Carbohydrate Res. 113:291-299.

Blumenkranz, N. and G. Asboe-Hansen. 1973. New method for quantitative determination of uronic acids. Anal. Biochem. 54:484-489. 
Bonghi, C., L. Ferrarese, B. Ruperti, P. Tonutti, and A. Ramina. 1998. Endo- $\beta$-1,4-glucanases are involved in peach fruit growth and ripening, and regulated by ethylene. Physiol. Plant. 102:346-352.

Buescher, R.W. and R.J. Furmanski. 1978. Role of pectinesterase and polygalacturonase in the formation of woolliness in peaches. J. Food Sci. 43:264-266.

Dawson, D.M., L.D. Melton, and C.B. Watkins. 1992. Cell wall changes in nectarines (Prunus persica): Solubilization and depolymerization of pectic and neutral polymers during ripening and in mealy fruit. Plant Physiol. 100:1203-1210.

Dawson, D.M., C.B. Watkins, and L.D. Melton. 1995. Intermittent warming affects cell wall composition of 'Fantasia' nectarines during ripening and storage. J. Amer. Soc. Hort. Sci. 120:1057-1062.

Dische, Z. 1962. Measurement of cell wall neutral sugars, p. 475-481. In: R.L. Whistler and M.L. Wolfrom (eds.). Methods in carbohydrate chemistry. Academic Press, New York.

Fisher, R.L. and A.B. Bennett. 1991. Role of cell wall hydrolases in fruit ripening. Annu. Rev. Plant Physiol. Plant Mol. Biol. 42:675-703.

Gross, K.C. 1982. A rapid and sensitive spectrophotometric method for assaying polygalacturonase using 2-cyanoacetamide. HortScience 17:933-934.

Harker, F.R. and P.W. Sutherland. 1993. Physiological changes associated with fruit ripening and the development of mealy texture during storage of nectarines. Postharvest Biol. Technol. 2:269-277.

Hinton, D.M. and R. Pressey. 1974. Cellulase activity in peaches during ripening. J. Food Sci. 39:783-785.

Hobbs, M.C., K.M. Easterbrook, and L.D. Melton. 1991. Cell wall material composition of mealy nectarines among ripening nectarines. J. Sci. Food Agr. 57:141-145.

Huber, D.J. 1983. Polyuronide degradation and hemicellulose modifications in ripening tomato fruit. J. Amer. Soc. Hort. Sci. 180:405-409.

Lill, R.E. 1985. Alleviation of internal breakdown of nectarines during cold storage by intermittent warming. Scientia Hort. 25:241-246.

Lill, R.E., E.M. O’Donoghue, and G.A. King. 1989. Postharvest physiology of peaches and nectarines. Hort. Rev. 11:413-452.
Lopez-Gomez, R. and M.A. Gomez-Lim. 1992. A method for extracting intact RNA from fruits rich in polysaccharides using ripe mango mesocarp. HortScience 27:440-442.

Lurie, S. 1992. Controlled atmosphere storage to decrease physiological disorders in nectarines. J. Intl. Food Sci. Tech. 27:507-514.

Lurie, S., A. Levin, L.C. Greve, and J.M. Labavitch. 1994. Pectic polymer changes in nectarines during normal and abnormal ripening. Phytochemistry 36:11-17.

McCollum, T.G., D.J. Huber, and D.J. Cantliffe. 1989. Modification of polyuronides and hemicelluloses during muskmelon fruit softening. Physiol. Plant. 76:303-308.

Pressey, R. and J.K. Avants. 1973. Separation and characterization of endopolygalacturonase and exopolygalacturonase from peaches. Plant Physiol. 52:252-256.

Sambrook, J., E.F. Fritsch, and T. Maniatis. 1989. Molecular cloning. Cold Spring Harbor Lab. Press, Cold Spring Harbor, New York.

Seymour, G.B., I.J. Colquhoun, M.S. Du Pont, K.R. Parsley, and R.R. Selvendran. 1990. Composition and structural features of cell wall polysaccharides from tomato fruits. Phytochemistry 29:725-731.

Sonego, L., A. Lers, A. Khalchitski, Y. Zutkhi, H. Zhou, S. Lurie, and R. Ben-Arie. 1999. Ethylene delays onset of woolly breakdown in coldstored peaches, p. 405-410. In: A. Kanellis (ed.). Biology and biotechnology of the plant hormone ethylene. Kluwer Academic Press, Dordrecht, The Netherlands.

Tonini, G., S. Brigati, and D. Caccioni. 1989. CA storage of nectarines: Influence of cooling delay, ethylene removal, low oxygen and hydrocooling on rots, over-ripening, internal breakdown and taste of fruit. Acta Hort. 254:335-340.

Von Mollendorff, L.J. and O.T. De Villiers. 1988. Role of pectolytic enzymes in the development of woolliness in peaches. J. Hort. Sci. 63:53-58.

Zhou, H.W., L. Sonego, R. Ben-Arie, and S. Lurie. 1999. Analysis of cell wall components in juice of 'Flavortop' nectarines during normal ripening and woolliness development. J. Amer. Soc. Hort. Sci. 124:424429. 